\title{
Foraminiferal indication of Eemian interglacial in the northern North Sea
}

\author{
ROLF W. FEYLING-HANSSEN
}

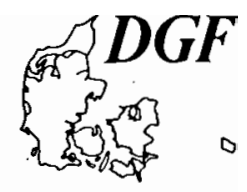

Feyling-Hanssen, R. W.: Foraminiferal indication of Eemian interglacial in the northern North Sea. Bull. geol. Soc. Denmark, vol. 29, pp. 175-189. Copenhagen, January 26th, 1981. https://doi.org/10.37570/bgsd-1980-29-12

Samples from a $120 \mathrm{~m}$ deep boring in the Statfjord Field of the northern North Sea revealed mostly glacial age foraminiferal assemblages, some of stadial and some of interstadial character. An assemblage of interglacial character occurred at $52 \mathrm{~m}$ below sea floor. This interglacial is called the Statfjord Interglacial and is probably correlatable with the Eemian of northwestern Europe. The boring is divided into eight biostratigraphical units, the paleoecology of which is discussed.

R. W. Feyling-Hanssen, Department of Micropaleontology, Institute of Geology, University of Aarhus, 8000 Arhus C, Denmark. $\quad$ April 22nd, 1980.

Twenty-seven undisturbed sediment samples from a $120 \mathrm{~m}$ deep boring, 2501, in the Statfjord $C$ Field of the Norwegian sector of the northern North Sea (fig. 1) were micropaleontologically processed and their fossil foraminifera content analyzed. The bore site lies to the west of the Norwegian Channel, at approximately $61^{\circ} 17.5^{\prime} \mathrm{N}$ and $1^{\circ} 54^{\prime} \mathrm{E}$. The present water depth is $\mathrm{c} .150 \mathrm{~m}$. The uppermost sample (no. 1) is from the present sea floor, the deepest (no. 34) from $113.5 \mathrm{~m}$ below the sea floor. All samples were rich in foraminifera, the richest one (no. 20) containing 81,500 specimens per $100 \mathrm{~g}$ sediment; no. 15 contained 27,100 and no. 17 contained 56,400 specimens per $100 \mathrm{~g}$ sediment. The poorest one contained 1,230 specimens per $100 \mathrm{~g}$ sediment. More samples than mentioned above were available in the upper part of the boring; their positions are indicated by short horizontal marks in the "Sample no." column of fig. 3a. These samples were not analyzed but were examined in connection with the placing of the foraminiferal zone boundaries.

From most of the analyzed samples $100 \mathrm{~g}$ dry weight was washed through sieves with mesh diameters $1.0 \mathrm{~mm}$ and $0.1 \mathrm{~mm}$. The foraminifera in the size fraction $0.1-1.0 \mathrm{~mm}$ were separated from the minerogenic particles of the sample using dibromethene diluted with ethylalcohol to specific weight $1.78 \mathrm{~g} / \mathrm{cm}^{3}$ (cf. Feyling-Hanssen, 1958, 1964; Feyling-Hanssen et al., 1971).

The benthonic and planktonic foraminifera were counted and calculated separately because they belong to different environments and only after death, as fossils, are they found together in the samples. The planktonic forms were only counted, not identified.

The foraminifera prove that the entire sediment sequence is of Quaternary age. Most of the Quaternary foraminifera are in a good state of preservation, indicating that they lived at the place where they were buried. Some samples, particularly those between $50 \mathrm{~m}$ and $80 \mathrm{~m}$ below sea floor, contained a considerable amount of reworked, worn, foraminifera of Upper Cretaceous

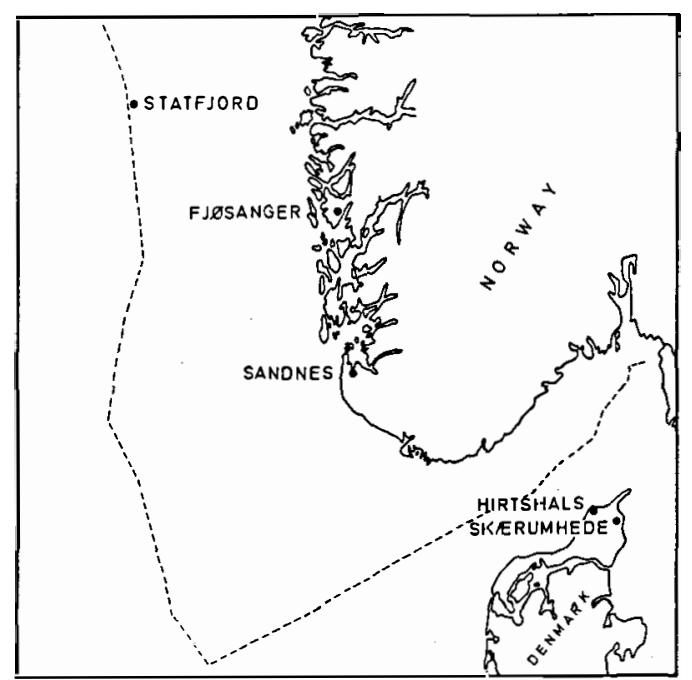

Fig. 1. Location of the investigated boring. 
origin (Fig. 3b), in addition to the Quaternary ones. This indicates that erosion of Upper Cretaceous rocks contributed some material for the Quaternary sediments.

Since the sediment of the boring is currently being studied and described by Tor Laken of The Norwegian Geotechnical Institute, Oslo, only a brief general treatment (based on a written communication with Løken, 1980) is given below.

Except for the uppermost sample which consists of fine sand, the sediment of the boring consists of clay. This clay is silty in the upper part, down to approximately $23 \mathrm{~m}$ below sea floor, and sandy in the lower part, from approximately $60 \mathrm{~m}$ below sea floor down to the deepest sample of the boring. In the middle part, $(23 \mathrm{~m}$ to $60 \mathrm{~m}$ below sea floor) some sandy layers and some silty parts occur in the clay. A general lithological column is given in fig. $3 \mathrm{~b}$, legend fig. 2 . A stone with largest diameter $3 \mathrm{~cm}$ occurred at $2.3 \mathrm{~m}$ and a smaller one at $3.6 \mathrm{~m}$ below sea floor. $\mathrm{A} 1 \mathrm{~cm}^{3}$ large stone was found $31.5 \mathrm{~m}$ below sea floor and another one of the same size at $85.5 \mathrm{~m}$. A small white chalk fragment occurred $31.5 \mathrm{~m}$ and another one 71.5. $\mathrm{m}$ below sea floor. These 4 stones and 2 chalk fragments were the only coarse minerogenic particles of the boring. Some molluscan shell fragments occurred $24.5 \mathrm{~m}$ below sea floor and one such fragment was noted at $77.5 \mathrm{~m}$.

\section{Range chart and diagrams}

A distinct zonation is revealed by the distribution of some benthonic foraminiferal species through the boring and by the frequency distribution of others, as illustrated by frequency symbols for 32 selected species in the range chart of fig. 3a. Legend of symbols are found in fig. 2 . This zonation is supported by the value of certain calculated parameters given as diagrams in fig. $3 b$. These parameters are:

1) The percentage of Boreal specimens in the benthonic assemblage of each sample. These percentages are made up of specimens of foraminiferal species which are known to live in the present day Boreal region, many of them even in the Lusitanian region. (For explanation of terminology cf. Antevs, 1928, p. 482; Hessland, 1943, p. 273; Feyling-Hanssen, 1955, p. 25). They represent an element of amelioration in the assemblages, so that cold and warm zones are distinguished by this diagram. The species which are considered Boreal in distribution and included in the present calculations are: Textularia sagittula, Defrance, Globulina gibba d'Orbigny, Angulogerina angulosa (Williamson), Bulimina marginata d'Orbigny, Bulimina gibba Fornasini, Stainforthia fusiformis (Williamson), Uvigerina peregrina Cushman, Bolivina alata Seguenza, Bolivina robusta Brady, Bolivina spathulata (Williamson), Cassidulina obtusa Williamson, Cassidulina laevigata d'Orbigny, Cassidulina teretis Tappan, Epistominella vitrea Parker, Hyalinea baltica (Schroeter), Planulina ariminensis d'Orbigny, Planulina bradyi Tolmachoff, Cibicides refulgens Montfort, Pullenia osloensis Feyling-Hanssen, Nonion barleeanum (Williamson), Elphidium albiumbilicatum (Weiss) (E. magellanicum Heron-Allen and Earland included), Elphidium incertum (Williamson), Elphidium margaritaceum Cushman, and Ammonia batavus (Hofker). Different forms of Elphidium excavatum (alba, clavata, selseyensis, cf. Feyling-Hanssen, 1972) occur in the material with forma clavata as the dominant one. They are all registered as Elphidium excavatum in the chart and none of them calculated with the Boreal element. A few of the above-mentioned species also occur in Arctic waters but are far more common in Boreal regions.

2) The faunal diversity, which, as defined by Walton (1964), is the number of ranked species in a counted assemblage whose percentage ac-

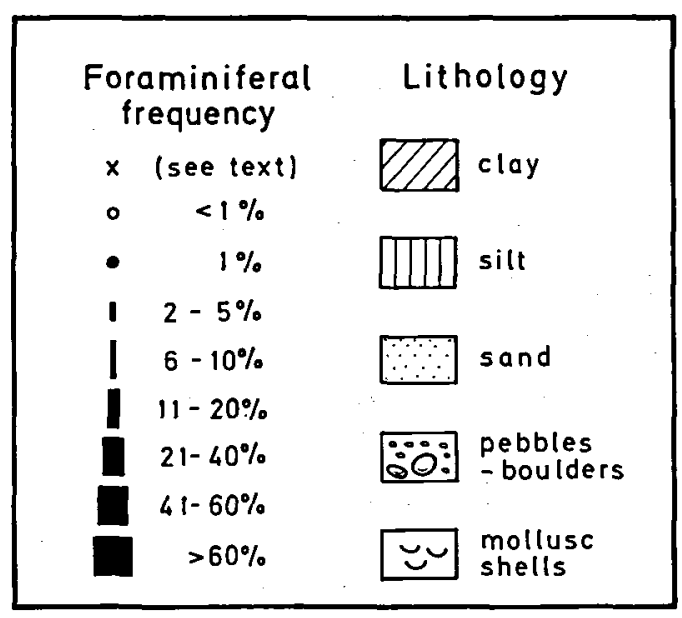

Fig. 2. Symbols used in the range chart and diagrams of fig. $3 \mathrm{a}$, $b, X$ indicates specimen observed only in the uncounted part of the sample. 
counts for $95 \%$ of the total benthonic assemblage. The trend of the diversity curve more or less follows that of the percentage of Boreal specimens.

3) The faunal dominance, which is simply the percentage of the most frequent species in a counted assemblage. High dominance is usually found in zones of extreme environment.

4) The number of benthonic Quaternary specimens of foraminifera per $100 \mathrm{~g}$ sediment has been extrapolated from the counted part of each sample. Besides reflecting favourable nutrient conditions, a high number of fossil foraminifera per unit sediment may reflect low sedimentation rate, whereas a low content of foraminifera may infer rapid sedimentation.

5) The percentage of planktonic Quaternary specimens per sample has been calculated. The planktonic foraminifera, mostly the species Globigerina pachyderma (Ehrenberg) and Globigerina bulloides d'Orbigny, were counted separately and their percentage of the total Quaternary assemblage, benthonic plus planktonic, calculated. High percentage of planktonic foraminifera may indicate open connection with an ocean, in this case the Norwegian Sea, and consequently, comparatively deep water.

6. Number of benthonic Quaternary species per sample.
7) Number of reworked Pre Quaternary specimens per $100 \mathrm{~g}$.

\section{Zonation}

The microbiostratigraphical subdivision of the boring is indicated to the left in fig. $3 a$ and $3 b$. Eight zones were distinguished and indicated by capital letters from $R$, youngest, to $Y$, oldest.

Zone $\mathrm{R}$ (Table 1 ) is represented by sample no. 1 at $0.0 \mathrm{~m}$, i.e., from the sea floor. It is the only sample dominated by planktonic foraminifera, $(53,600$ planktonic specimens/100 g sediment and 27,800 benthonic specimens $/ 100 \mathrm{~g}$ sediment) the planktonic specimens making $66 \%$ of the total assemblage. Globigerina bulloides d'Orbigny and G. pachyderma (Ehrenberg) dominates, but Globorotalia inflata. (d'Orbigny) and Orbulina universad'Orbigny are also present. The Boreal element is as high as $90 \%$ and the most frequent benthonic species are Cassidulina laevigata, $46 \%$, and Angulogerina angulosa, 19\%. This sample represents the present, and most probably also the Holocene, conditions of the bore site. This is the only level of the boring that water depth as great as $150 \mathrm{~m}$ and free ocean connection is indicated by the foraminifera. The water temperature

Table 1, Zone $\mathbf{R}$

Sample no. 1 , depth $0.0 \mathrm{~m}$, weight $100 \mathrm{~g}$

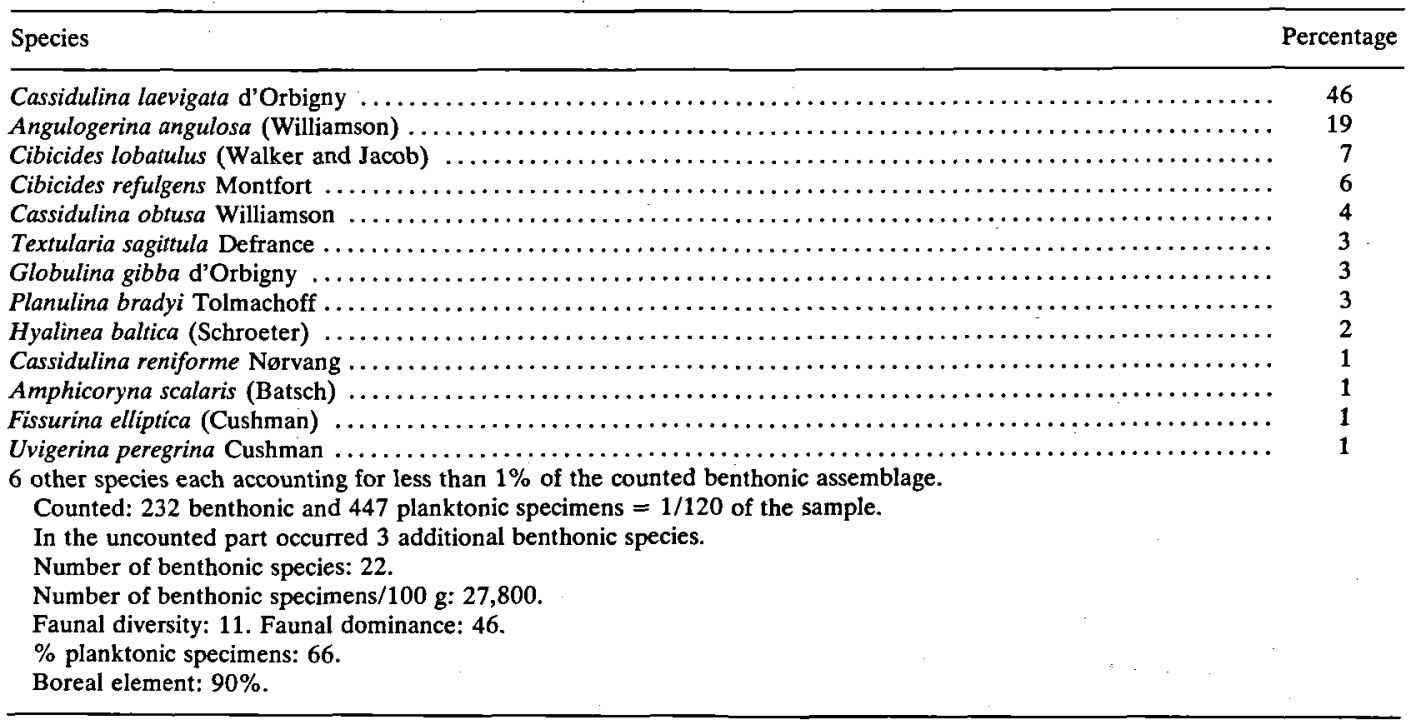




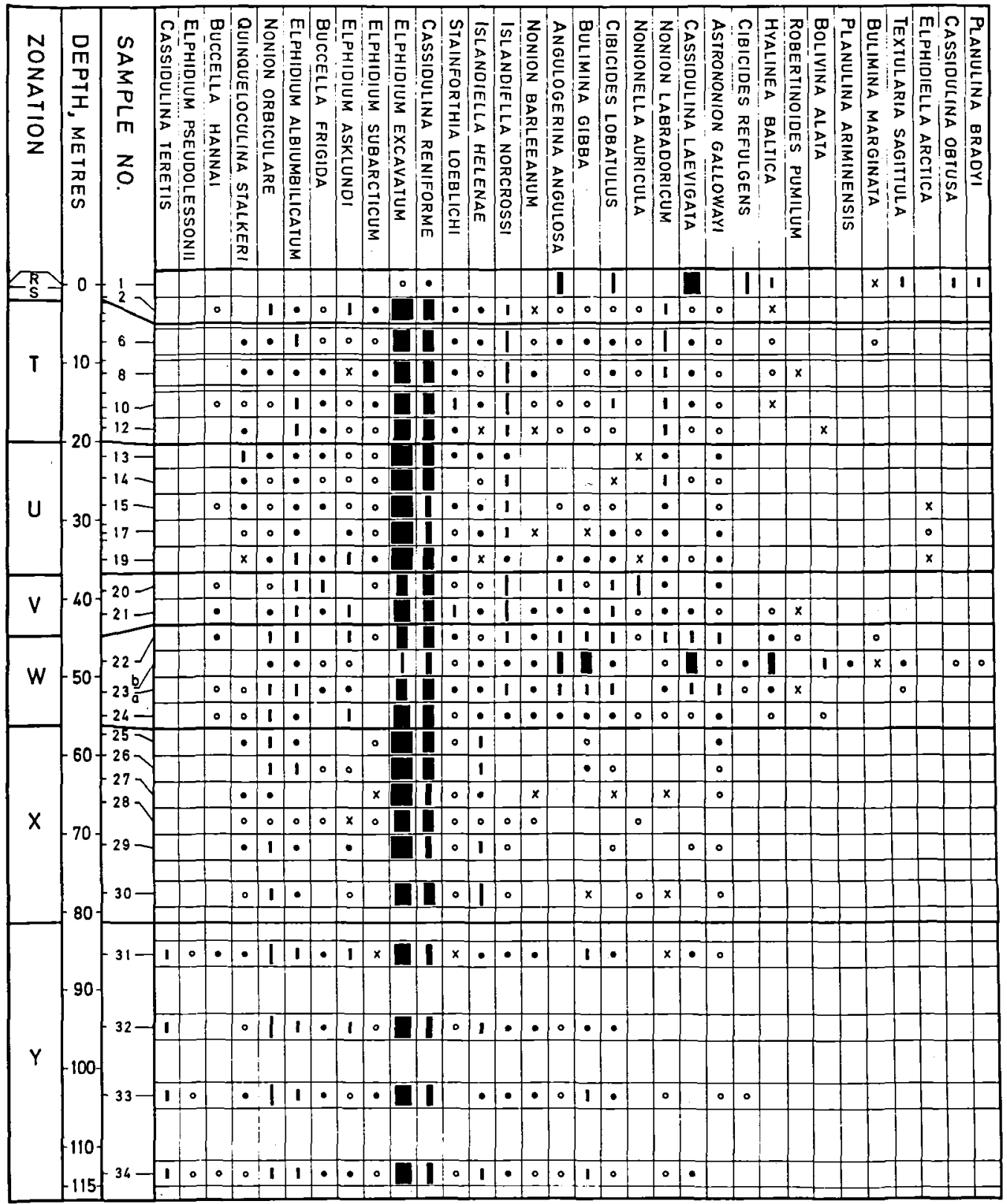

Fig. 3a. Range chart for boring 2501.

is most probably also higher than any of the water temperatures indicated by the other samples of the boring.

Zone $\mathrm{S}$ is represented by no. 2 at $1.5 \mathrm{~m}$ depth below sea floor. The assemblage is an Arctic one with dominance of the species Elphidium excavatum (Terquem), forma clavata Cushman,
$62 \%$, and with Cassidulina reniforme Nørvang (= C. crassa of authors, cf. Sejrup and Guilbault, $1980), 24 \%$, next in frequencey. The Boreal element is only $2 \%$ and the diversity is 8 . Still there is a considerable number of benthonic species, 31 , and the number of benthonic specimens per $100 \mathrm{~g}$ sediment is 16,400 . There are very few planktonic specimens (1\%). 


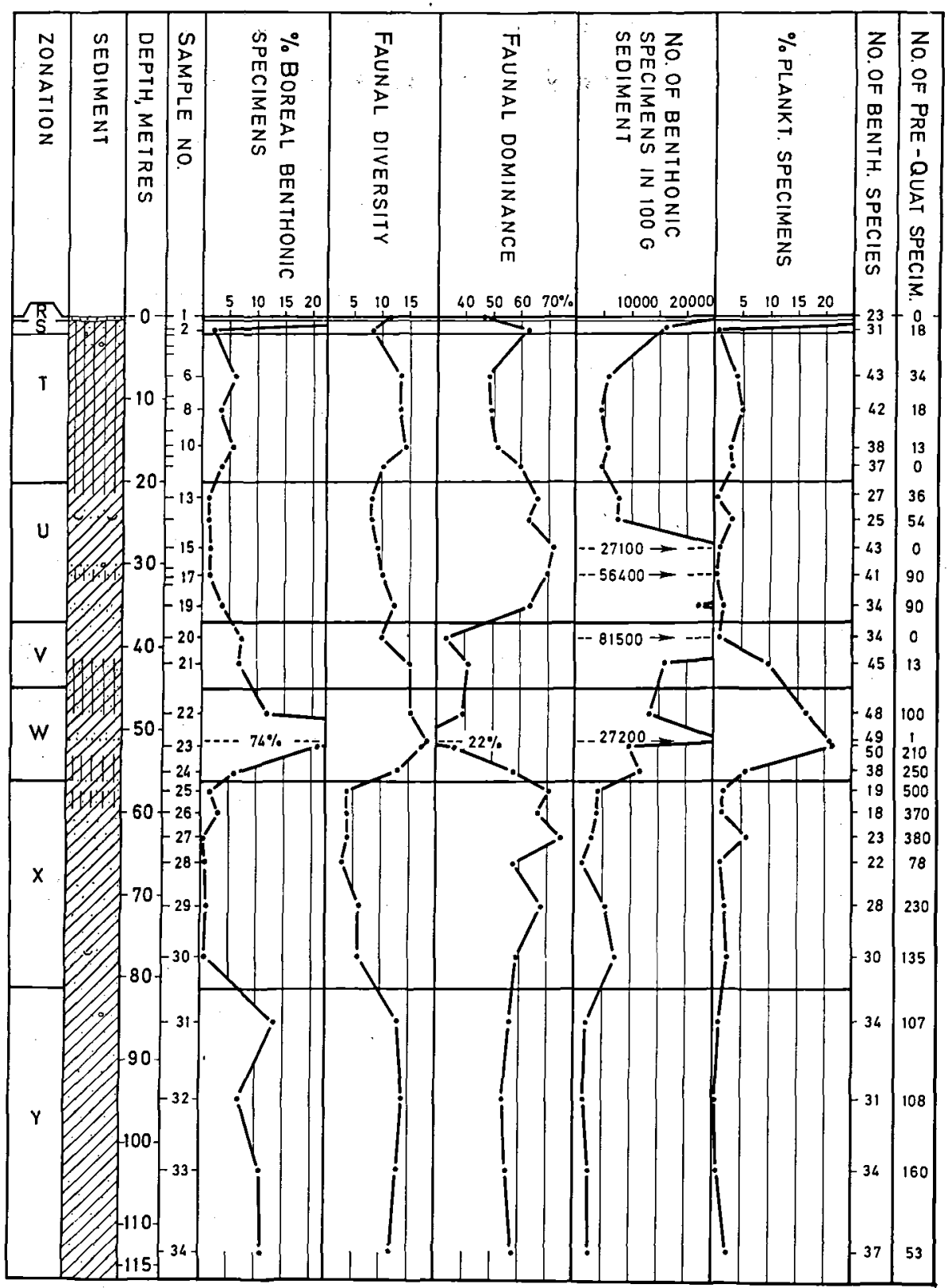

Fig. 3b. Diagrams for boring 2501.

This zone probably represents a stadial age of a glacial stage in the area.

The marine-climatic conditions during sedimentation were Arctic, and the salinity was close to normal marine.

The water depth was probably a little more than $20 \mathrm{~m}$.
Zone T (Table 2) is represented by nos. 6 to 12 . The zone boundaries are placed at $2.0 \mathrm{~m}$ and 20.0 $\mathrm{m}$ below sea floor. The assemblages of this zone are also Arctic but with an admixture of Boreal specimens. The Boreal element varies from $6 \%$ to $3 \%$ with an average of $5 \%$.

This zone represents an interstadial age of a 
Table 2, Zone T

Sample no. 6, depth $7.3 \mathrm{~m}$, weight $100 \mathrm{~g}$

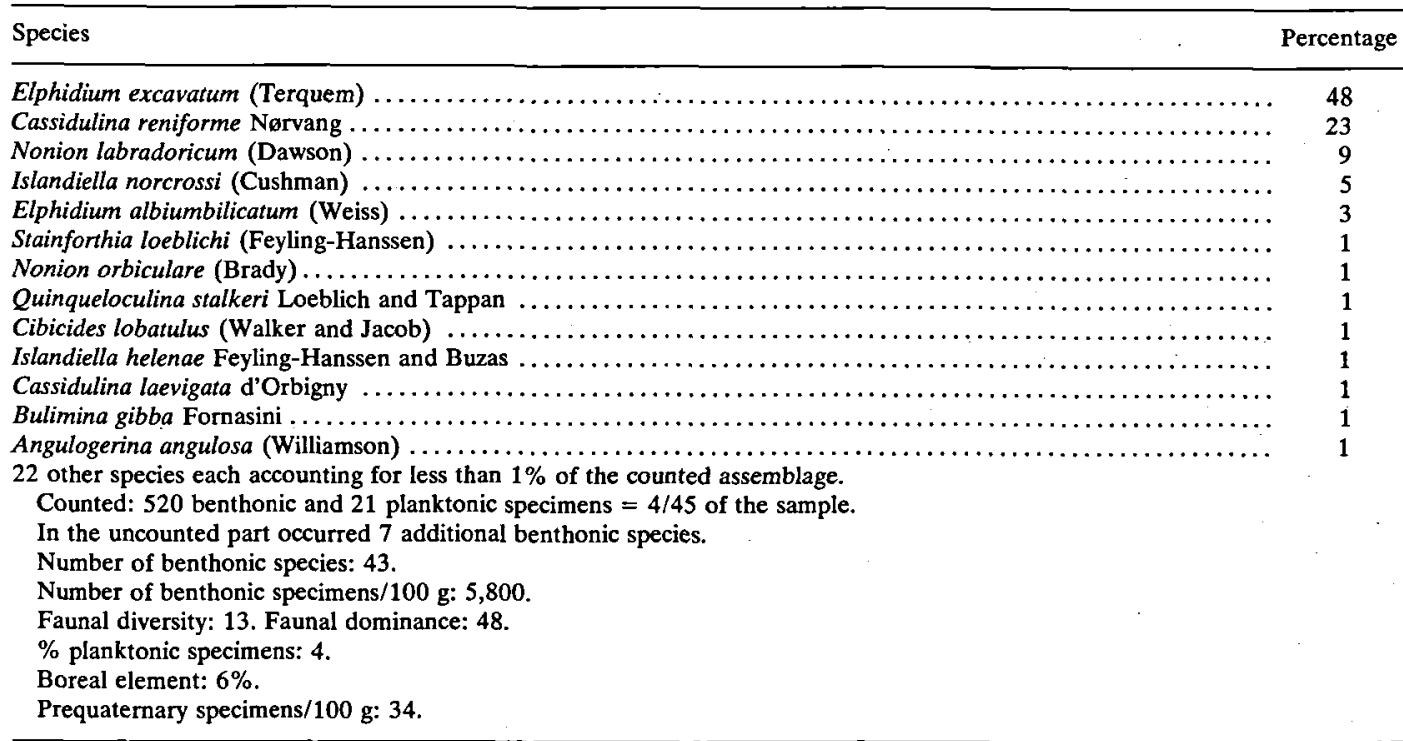

glacial stage in the area. The average diversity of the zone is $\mathbf{1 3}$ and the average number of different species 40 . The number of benthonic specimens per $100 \mathrm{~g}$ sediment varies from 4,550 to 5,840 with an average of 5,200 . There are more planktonic specimens in this zone than in zone $S$, on an average they make $4 \%$ of the total fauna.

Elphidium excavatum and Cassidulina reniforme are the most frequent species in this zone also but the dominance of $E$. excavatum is less pronounced, averaging $52 \%$. A characteristic feature of the zone is the remarkably high fre- quency of Islandiella norcrossi (Cushman) and Nonion labradoricum (Dawson), which both average $5 \%$. Elphidium albiumbilicatum is common and Elphidium groenlandicum Cushman is present in three of the analyzed samples of the zone.

The marine-climatic conditions during sedimentation were Middle to Low-Arctic as indicated by the quite distinct Boreal element of the fauna, the salinity was close to normal marine, and the depth was more than $20 \mathrm{~m}$ but probably less than $80 \mathrm{~m}$.

Table 3, Zone U

Sample no. 15, depth $28.0 \mathrm{~m}$, weight $100 \mathrm{~g}$

Species

Percentage

Elphidium excavatum $($ Terquem) $\ldots \ldots \ldots \ldots \ldots \ldots \ldots \ldots \ldots \ldots \ldots \ldots, \ldots \ldots \ldots \ldots \ldots \ldots \ldots \ldots \ldots \ldots \ldots, \ldots \ldots$

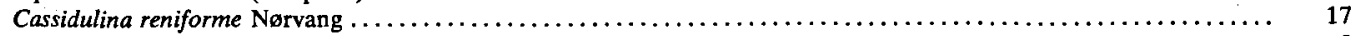

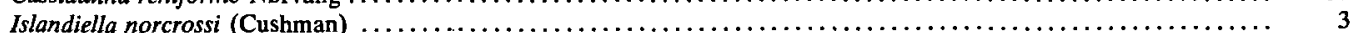

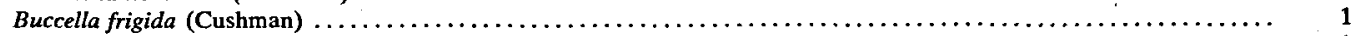

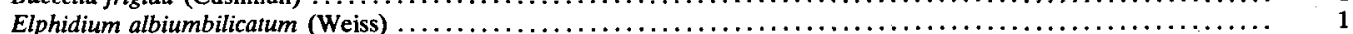

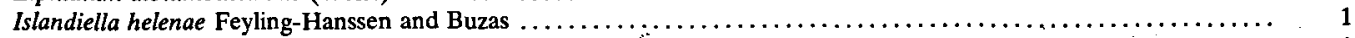

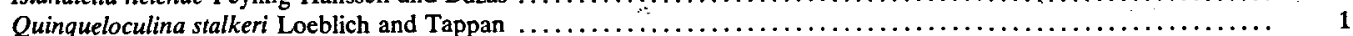

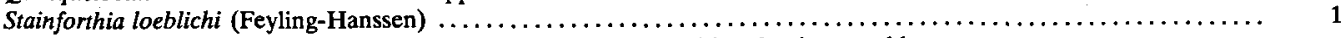

21 other species each accounting for less than $1 \%$ of the counted benthonic assemblage.

Counted: 602 benthonic and 6 planktonic specimens $=1 / 45$ of the sample.

In the uncounted part occurred 14 additional benthonic species.

Number of benthonic species: 43 .

Number of benthonic specimens/100 g: 27,100.

Faunal diversity: 9. Faunal dominance: 71 .

$\%$ planktonic specimens: 1.

Boreal element: $2 \%$. 
Zone $U$ (Table 3 ) is represented by nos. 13 to 19. The zone boundaries are placed at $20.0 \mathrm{~m}$ and $37.0 \mathrm{~m}$ below sea floor. The assemblages of this zone are Arctic. The Boreal element is less than $2 \%$ on average.

This zone represents a stadial age of a glacial stage in the area.

The average diversity of the zone is 9 and the average number of different benthonic species per sample 34 . The average number of benthonic specimens per $100 \mathrm{~g}$ sediment decreases from $35,300(\max .56,400)$ in the lower part to 7,700 (min. 7,500) in the upper part of the zone. Planktonic specimens consist, on an average, $1 \%$ of the total fauna.

The dominance of Elphidium excavatum forma clavata is more pronounced in this zone than in the overlying one, the average being $66 \%$. Islandiella norcrossi, Nonion labradoricum, Elphidium albiumbilicatum, Elphidium asklundi Brotzen, Nonion orbiculare (Brady) (cf. Hansen and Lykke-Andersen, 1976), Buccella frigida (Cushman) and Quinqueloculina stalkeri Loeblich and Tappan are usually met with in the zone but only in low percentages, $<1 \%-3 \%$. Elphidiella arctica (Parker and Jones) is present in three of the investigated samples.

The marine-climatic conditions during sedimentation of this zone were close to High-Arctic. The salinity was normal marine, and the water depth was probably less than in the overlying zone. The high number of specimens per $100 \mathrm{~g}$ sediment, particularly in the lower part of the zone, may be explained by high content of nutrients in such Arctic water, but it seems more reasonable to assume a low sedimentation rate at the bore site during this zone. The issue of sediment-loaded melt-water most probably decreases during the cold, frozen, intervals of an ice age.

Zones $S, T$ and $U$ thus mirror ice age conditions with low admixture of Boreal specimens in the foraminiferal assemblages, with lowered sea level and little connection with an open ocean.

Zone $\mathrm{V}$ is represented by nos. 20 and 21 . The zone boundaries are placed at $37.0 \mathrm{~m}$ and $44.8 \mathrm{~m}$ below the sea floor. The assemblages of this zone are Boreo-Arctic. The Boreal element of the faunas is $7 \%$.

This zone represents a mild post interglacial or pre glacial stage in the area.
The average faunal diversity of the zone is $\mathbf{1 3}$ and the average faunal dominance 37 . In no. 20 there were registered 34 different benthonic species of foraminifera, in no. 21 there were 45. The number of benthonic specimens per $100 \mathrm{~g}$ sediment was 85,100 in no. 20 , and 16,000 in no. 21 . The percentage of planktonic specimens decreases in this zone from $10 \%$ in no. 21 to $1 \%$ in no. 20 , probably indicating a shallowing of water depth.

Elphidium excavatum is less dominant in zone $\mathrm{V}$ than in the overlying zone, its average frequency being $37 \%$ of the benthonic fauna. A characteristic feature of the zone is the presence of Boreal species such as Angulogerina angulosa, Bulimina gibba, Cassidulina laevigata and Nonion barleeanum and at the same time a consistent occurrence of Islandiella norcrossi and presence of Nonion labradoricum and Astrononion gallowayi Loeblich and Tappan. Elphidium albiumbilicatum and Cibicides lobatulus (Walker and Jacob) make each up an average of $3 \%$.

A remarkable frequency increase of Nonionella auricula Heron-Allen and Earland takes place in this zone, from $<1 \%$ in no. 21 to $8 \%$ in no. 20 .

The marine-climatic conditions during sedimentation of zone $\mathrm{V}$ were Boreo-Arctic, that is, still firmly ameliorated but developing from more to less favourable conditions from the preceding to the following zone. Boreal and Boreo-Lusitanian species disappear through this zone, i.e., they occur in no. 21 but are absent or rarer in no. 20, such as Robertinoides pumilum Höglund, Nonion barleeanum, Cassidulina laevigata, Hyalinea baltica and Bulimina gibba, and in addition Sigmoilopsis schlumbergeri (Silvestri), Uvigerina peregrina, Bolivina alata. Shallowing takes place from deeper water during the preceding zone, and consequently the influx of Atlantic water decreased. The sedimentation rate seems to have been low so that a short length of core may cover a considerable time-span.

Zone W (Table 4) should strictly be represented only by one sample (no. 23b), which represents a thin sandy layer in the otherwise clayey sample no. 23 from $52 \mathrm{~m}$ below sea floor. This clayey part is (no. 23a) placed below the sandy part of the sample in the chart of fig. 3a. But because of a quite high content of Boreal specimens nos. 23 
and 22 are also referred to this zone, as is no. 24 . An interglacial development starts in no. 24 , and the faunal break between this sample and the underlying no. 25 is particularly distinct. The zone boundaries are thus placed at $44.8 \mathrm{~m}$ and $56.2 \mathrm{~m}$ below sea floor.

The sand sample no. $23 \mathrm{~b}$ contained a Boreal foraminiferal fauna characterized by Bulimina gibba, 22\%, and Cassidulina laevigata $21 \%$. Other frequent species were Angulogerina angulosa, $11 \%$, Hyalinea baltica, 11\%, Cassidulina reniforme, $11 \%$, and Elphidium excavatum (forma clavata, alba Feyling-Hanssen and selseyensis Heron-Allen and Earland) $8 \%$. Conspicuous by its size, though not frequent, is Planulina ariminensis, $1 \%$. The specimens of the sample were in good state of preservation.

Sample no. $23 \mathrm{~b}$ represents an interglacial stage which is here called the Statfjord Interglacial. The boreal element is as high as $74 \%$. The bore site of the present boring is the type locality of this Statfjord Interglacial, the boring its type section, and the stratum represented by no. $23 \mathrm{~b}$ its type stratum. The other samples of zone $\mathrm{W}$ are also referred to this interglacial.

Compared with the uppermost sample of the boring (no. 1), which represents the present interglacial, i.e. the Holocene, the assemblage of no. $23 \mathrm{~b}$ is so distinct that any suspicion that the latter represents downfall of no. 1 in the borehole can be ruled out. Whereas the assemblage of no. $23 \mathrm{~b}$ is predominated by Bulimina gibba, this species does not occur at all in the assemblage of no. 1 , and its closest relative, Bulimina marginata was only observed in the uncounted part of that sample. The sampling procedure itself would also preclude the possibility of such contamination.

The Boreal element is lower $(74 \%)$ in no. $23 \mathrm{~b}$ than in no. 1 , where it is $90 \%$. This may indicate that the Statfjord Interglacial was cooler than that represented by no. 1 , or it may mean that zone $\mathrm{W}$, even no. $23 \mathrm{~b}$, does not represent the optimum of the interglacial. Similarly, the ratio planktonic foraminifera/total assemblage (benthonic + planktonic) is considerably lower $(21 \%)$ for no. $23 \mathrm{~b}$ than for no. $1(66 \%)$. Again, this may infer that the rise of sea level was less during the interglacial of no. $23 \mathrm{~b}$ than during that of the present interglacial (the Holocene), or it may mean that no. $23 \mathrm{~b}$ was not deposited during the maximum transgression of its interglacial.

Among the planktonic species of zone $\mathrm{W}$ are

Table 4, Zone W

Sample no. 23b, depth $52.0 \mathrm{~m}$, weight $35 \mathrm{~g}$

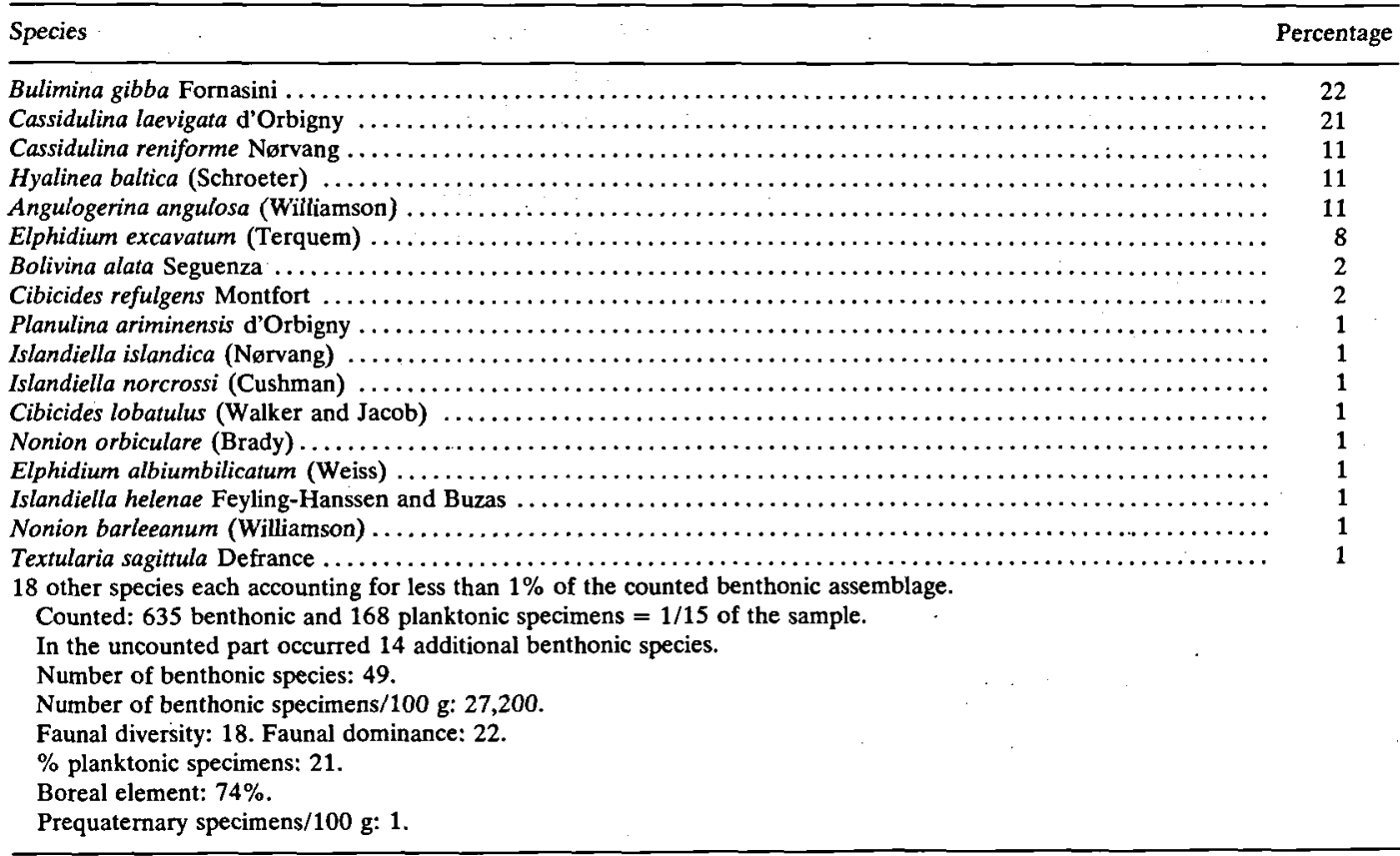


Table 5, Zone X

Sample no. 25, depth $57.5 \mathrm{~m}$, weight $100 \mathrm{~g}$

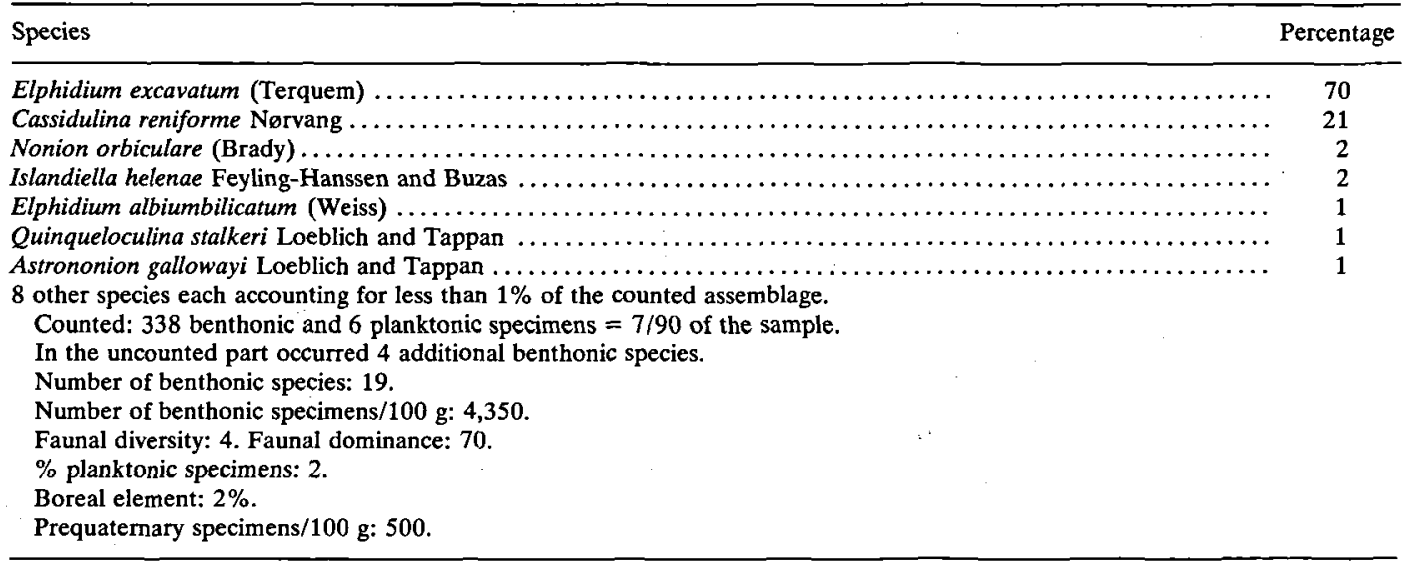

mostly Globigerina bulloides and Globigerina pachyderma, but also a few Globorotalia inflata and Orbulina universa occur.

The amount of planktonic foraminifera is as great in no. 23a as in no. 23b, but in the overlying sample (no. 22) it has decreased to $16 \%$. The Boreal element is $21 \%$ in no. $23 \mathrm{a}$ and decreases after the maximum in no. $23 \mathrm{~b}$ to $12 \%$ in no. 22 .

Zone $\mathrm{W}$ displays the highest number of different benthonic species of all the zones of the boring (fig. $3 \mathrm{~b}$ ), ranging from 38 to 50 , the average being 46 . The number of benthonic specimens per $100 \mathrm{~g}$ sediment increases from 11,700 in no. 24 to 27,200 in no. $23 \mathrm{~b}$, and then drops to 13,200 in the uppermost sample of the zone.

Zone $\mathrm{W}$ has the lowest faunal dominance of all the zones (average $38 \%$ ) no. $23 \mathrm{~b}$ holding a minimum of $22 \%$. On the other hand, the faunal diversity is remarkably high, the average value being 16.

Zone $X$ (Table 5) is represented by nos. 25 to 30 (fig. $3 \mathrm{a}, \mathrm{b}$ ). The zone boundaries are placed at $56.2 \mathrm{~m}$ and $81.5 \mathrm{~m}$ below sea floor. The assemblages of this zone are High Arctic. The Boreal element of the faunas ranges from zero to $3 \%$, the average value being $1 \%$, which is the lowest of all the zones in the boring.

This zone represents a glacial stage or a stadial within a glacial stage.

The average diversity of the zone is 4 , which is again the lowest of all the zones of the boring. The average number of benthonic species is 23 .
The number of benthonic specimens per $100 \mathrm{~g}$ sediment ranges from 1,200 to 7,400 , the average being 4,200 . The planktonic specimens are few in most of the samples, a single maximum of $6 \%$ occurs in no. 27 . The average for the zone is 2-3\%.

Features of this zone are a high frequency of Elphidium excavatum forma clavata - on average this form constitutes $66 \%$ of the benthonic faunas - and a comparatively low number of different benthonic species per sample (19-30). Another characteristic is a firm representation of large, glistening forms of the Arctic species Islandiella helenae Feyling-Hanssen and Buzas particularly in the lower part of the zone. A third peculiarity of the zone is that many tests of Elphidium excavatum are remarkably small and flat, and tests of Cassidulina reniforme are also notably small.

The marine-climatic conditions during sedimentation of this zone were High Arctic, and the salinity may have been reduced in comparison to normal marine salinity. This, possibly in connection with some turbidity of the water, is thought to have caused depauperation of some of the species. The water depth seems to have been fairly shallow, probably about $20 \mathrm{~m}$, during the greater part of the zone. The specimens are well preserved.

Zone Y (Table 6) is represented by the nos. 31 to 34. The upper zone boundary is placed at $81.5 \mathrm{~m}$; the lower boundary is not known. The assemblages of this zone are Boreo-Arctic. The 
Table 6, Zone $\mathrm{Y}$

Sample no. 31, depth $86.0 \mathrm{~m}$, weight $100 \mathrm{~g}$

Species

Percentage

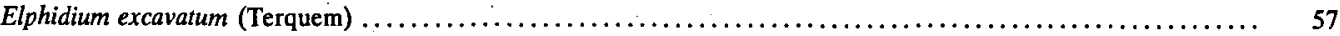

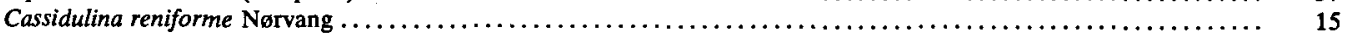

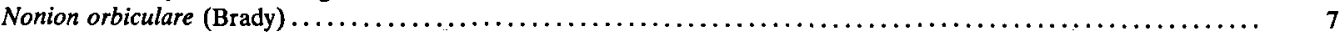

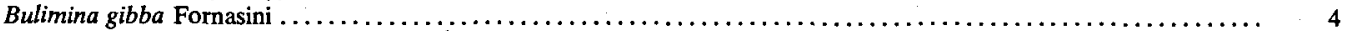

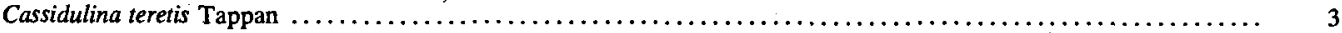

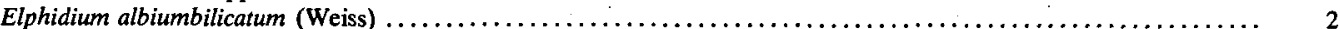

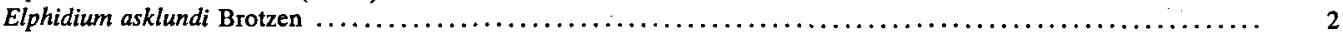

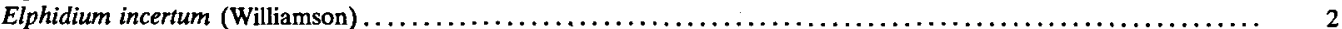

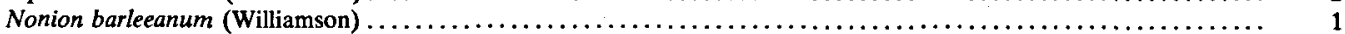

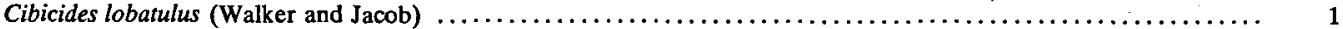

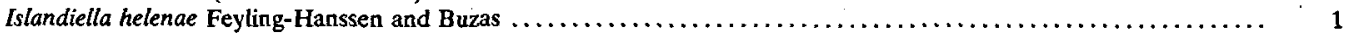

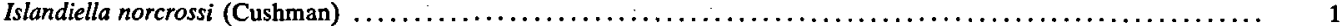

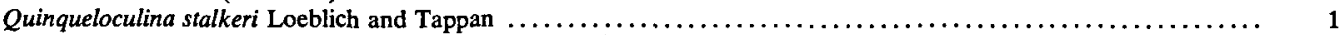

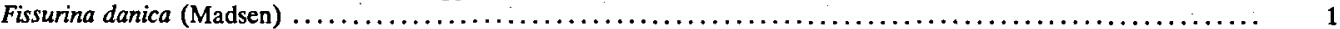

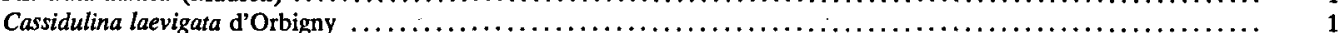

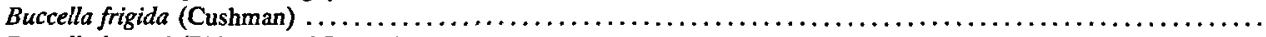

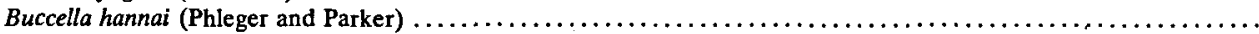

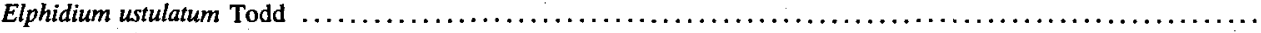

7 other species each accounting for less than $1 \%$ of the counted benthonic assemblage.

Counted: 390 benthonic and 4 planktonic specimens $=8 / 45$ of the sample.

In the uncounted part occurred 9 additional benthonic species.

Number of benthonic species: 34 .

Number of benthonic specimens/100 g: 2,200

Faunal diversity: 13. Faunal dominance: 57.

$\%$ planktonic specimens: 1 .

Boreal element: $13 \%$.

Prequaternary specimens/100 g: 107.

Boreal element of the assemblages ranges from $7 \%$ to $13 \%$, (average $11 \%$ ) which represents a firm admixture of Boreal specimens.

This zone thus represents a mild interval, indicating interstadial conditions, maybe even approaching interglacial conditions.

The average diversity is 13 , the average number of benthonic species per sample is 34 , and the average number of benthonic specimens per $100 \mathrm{~g}$ sediment is 2,100 . There are only few planktonic specimens, averaging $1 \%$ of the total assemblage.

Characteristic of the zone is a quite high frequency of Nonion orbiculare and Elphidium albiumbilicatum; Cassidulina teretis is present and a few Elphidium pseudolessonii Ten Dam and Reinhold. Bulimina gibba occurs in all samples. There is a remarkably high content of typical shallow-water species in zone $\mathrm{Y}$, between $15 \%$ and $10 \%$ of the combined assemblages, benthonic + planktonic. This zone was most likely deposited in the shallowest water represented by the present boring. The salinity was close to normal marine and the sedimentation rate probably high.

\section{Age and Correlation}

The interglacial age represented by zone $\mathrm{W}$ of the present boring is probably the Eemian. But

\section{PLATE 1}

1, Textularia sagittula Defrance, zone W. 2, Quinqueloculina stalkeri Loeblich and Tappan, zone X. 3, Globulina gibba d'Orbigny var. myristiformis (Williamson), zone R. 4, Angulogerina fluens Todd, zone V. 5, Stainforthia loeblichi (Feyling-Hanssen), zone W. 6 , Stainforthia loeblichi (Feyling-Hanssen), zone V. 7, Uvigerina peregrina Cushman, zone T. 8, Uvigerina peregrina Cushman, zone W. 9, Angulogerina angulosa (Williamson), zone W. 10, Angulogerina angulosa (Williamson), zone R. 11, Bolivina alata Seguenza, zone W. 12, Bolivina robusta Brady, zone W. 13, 14, 15, 16, Bulimina gibba Fornasini, zone W. 17, 18, Bulimina marginata d'Orbigny, zone W. 19, 20, Cassidulina laevigata d'Orbigny, zone R. 21, Cassidulina laevigata d'Orbigny, zone W. 22, Cassidulina teretis Tappan, zone Y. 23, Cassidulina reniforme Narvang, zone X. 24, Islandiella helenae Feyling-Hanssen and Buzas, zone X. 25, 26, Islandiella norcrossi (Cushman), zone T. 27, 28, 29, Cibicides refulgens Montfort, same specimen, zone R. 30, Robertinoides pumilum Höglund, zone T: Magnification: All $\times 60$. 


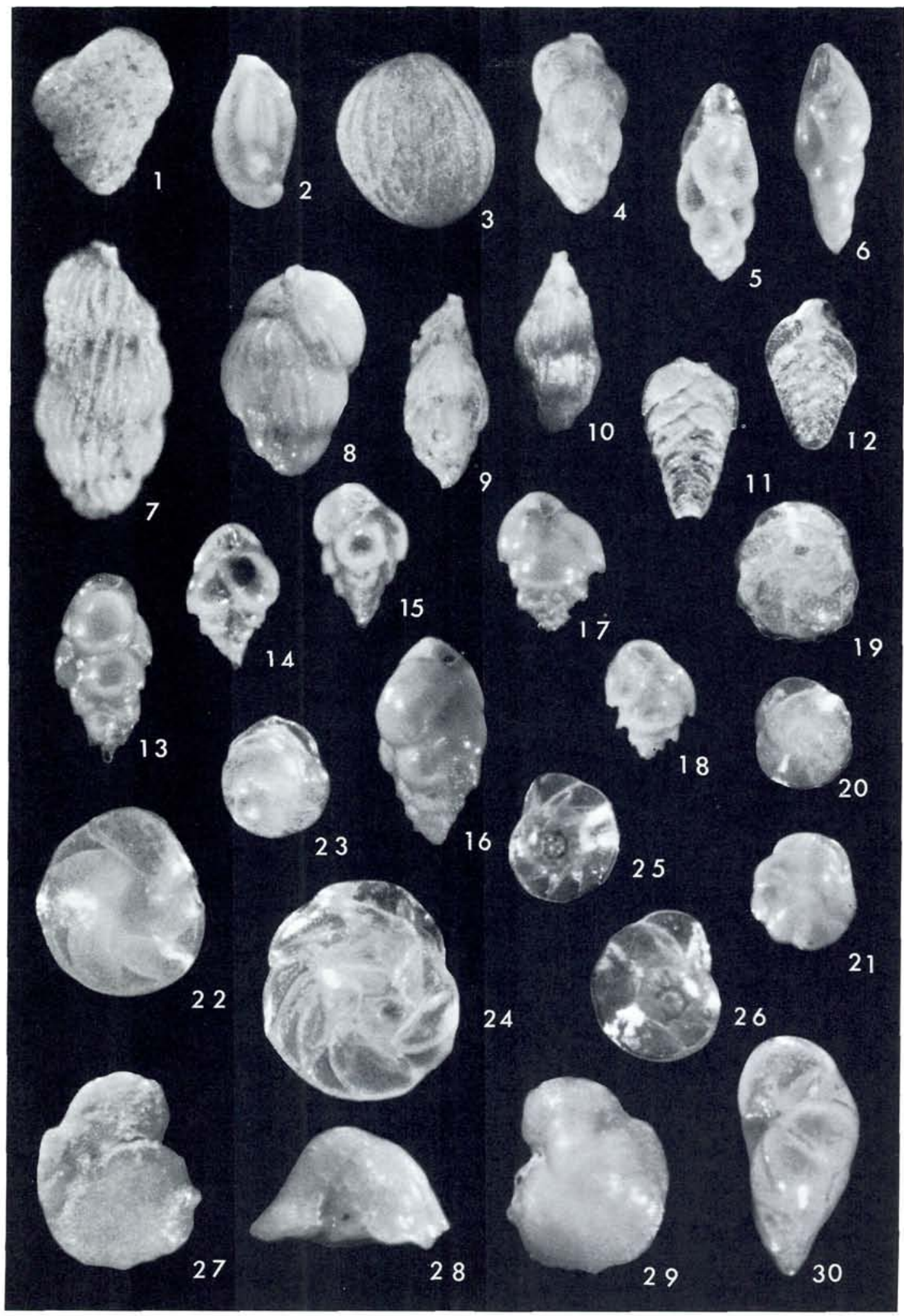


theoretically it could represent any interglacial age, e.g., the Holsteinian: Sedimentation was probably not continuous at the bore site. Records of both glacial and interglacial age may be lacking. Holocene sediments, representing the present interglacial - from 10,000 years BP to the present day - are rare or extremely thin in the North Sea except in depressions and channels (Lange, 1956; Moyes et al., 1974; Holmes, 1977; Jansen et al., 1979a). If similar sedimentary conditions prevailed during earlier interglacials, their sediments may easily have escaped sampling in an area such as that of the present locality. There are many other examples of borings in the North Sea where an interglacial does not show up, even though the borings seem deep enough to contain such layers, e.g., the borings from the Frigg field and Booster Station (Løfaldli, 1973). Therefore, when an interglacial layer accidentally occurs among the samples, it may be of an early as well as of a late interglacial age. There is also scanty stratigraphical guidance to be obtained from ice age layers above and below, since such deposits seem to be very much alike whatever ice age they belong to.

Zone W seems, however, to belong in the later part of the Quaternary because no species of Early Quaternary age, e.g., Cassidulina teretis Tappan or Elphidiella hannai (Cushman and Grant) (van Voorthuysen, 1949a, b; van Voorthuysen et al., 1972; Funnell, 1961; Feyling-Hanssen, 1980) occur in it. This might be a question of water depth, but hardly exclusively so. If zone $\mathrm{W}$ is to be placed in the Late Quaternary, the preceding High-Arctic zone $X$ might well represent the great ice age, the Saalian, or parts of it.

Similarities are found between the assemblage of no. 23b of zone $W$ and assemblages from the Eemian of Fjøsanger, Bergen (Sejrup, 1978); in particular the upper part of zone F4 of the Fjøsanger section is notably comparable. But there are also great differences, which is quite natural since the assemblage of no. 23b represents an outer shelf fauna while those from Fjøsanger are fjord faunas. Eemian foraminiferal assemblages described from southern Denmark (Konradi, 1976; Sørensen, 1980), and northern Germany (Lafrenz, 1963) reflect extreme shallow-water conditions and are mostly composed of Elphidium and Nonion species, Ammonia batavus and Bucella frigida. This applies also to the Eemian of Amersfoort, the Netherlands (van Voorthuysen, 1957), particularly for the upper part of that sequence. In addition the salinity was found to have been much reduced in the Eemian of Amersfoort.

The closest correlation is found between the assemblage of no. $23 \mathrm{~b}$ and some foraminiferal assemblages from the Skrrumhede boring of 1905 , left by the late Dr. A. Nørvang. The boring was described by Jessen et al. (1910) but a study of its foraminifera was not published. Assemblages from the lower part of the Eemian Turritella terebra zone of that boring, particularly from about 153 to $169 \mathrm{~m}$ depth below surface, show great similarity to the assemblage of no. 23b of the present North Sea boring. Bulimina gibba, Cassidulina laevigata and Hyalinea baltica are frequent and Planulina ariminensis is common. But there are more Sigmoilopsis schlumbergeri (Silvestri) in the Eemian of Skærumhede, and Ammonia batavus and Quinqueloculina borea Gudina and Globobulimina turgida (Bailey) are quite characteristic. Cassidulina reniforme and Elphidium excavatum are not present in the foraminiferal collection from this part of the old Skærumhede boring. It should be mentioned that below the warm-water assemblages of the Turritella terebra zone, or in the lowest part of this zone, cold-water assemblages with many specimens of Islandiella helenae occur.

A Skærumhede II boring, micropaleontologically investigated by Knudsen and Konradi (Bahnson et al., 1974; Knudsen, 1976) only penetrated the upper part of the Eemian con-

PLATE 2

1, 2, Planulina ariminensis d'Orbigny, same specimen, zone W. 3, 4, Hyalinea baltica (Schroeter), zone W. 5, Nonion barleeanum (Williamson), zone V. 6, Cibicides lobatulus (Walker and Jacob), zone R. 7, 8, Nonionella auricula Heron-Allen and Earland, same specimen, zone V. 9, Buccella tenerrima (Bandy), zone V. 10, 11, Nonion orbiculare (Brady), same specimen, zone V. 12, 13, Nonion labradoricum (Dawson), same specimen, zone V. 14, Astrononion gallowayi Loeblich and Tappan, zone U. 15, 16, Elphidium albiumbilicatum (Weiss), zone T. 17, Elphidium subarcticum Cushman, zone W. 18, Elphidium asklundi Brotzen, zone X. 19, Elphidiella arctica (Parker and Jones), zone U. 20, 21, Elphidium excavatum Terquem) forma clavata Cushman, zone X. Magnification: Fig. $19 \times 45$, all the others $\times 60$. 


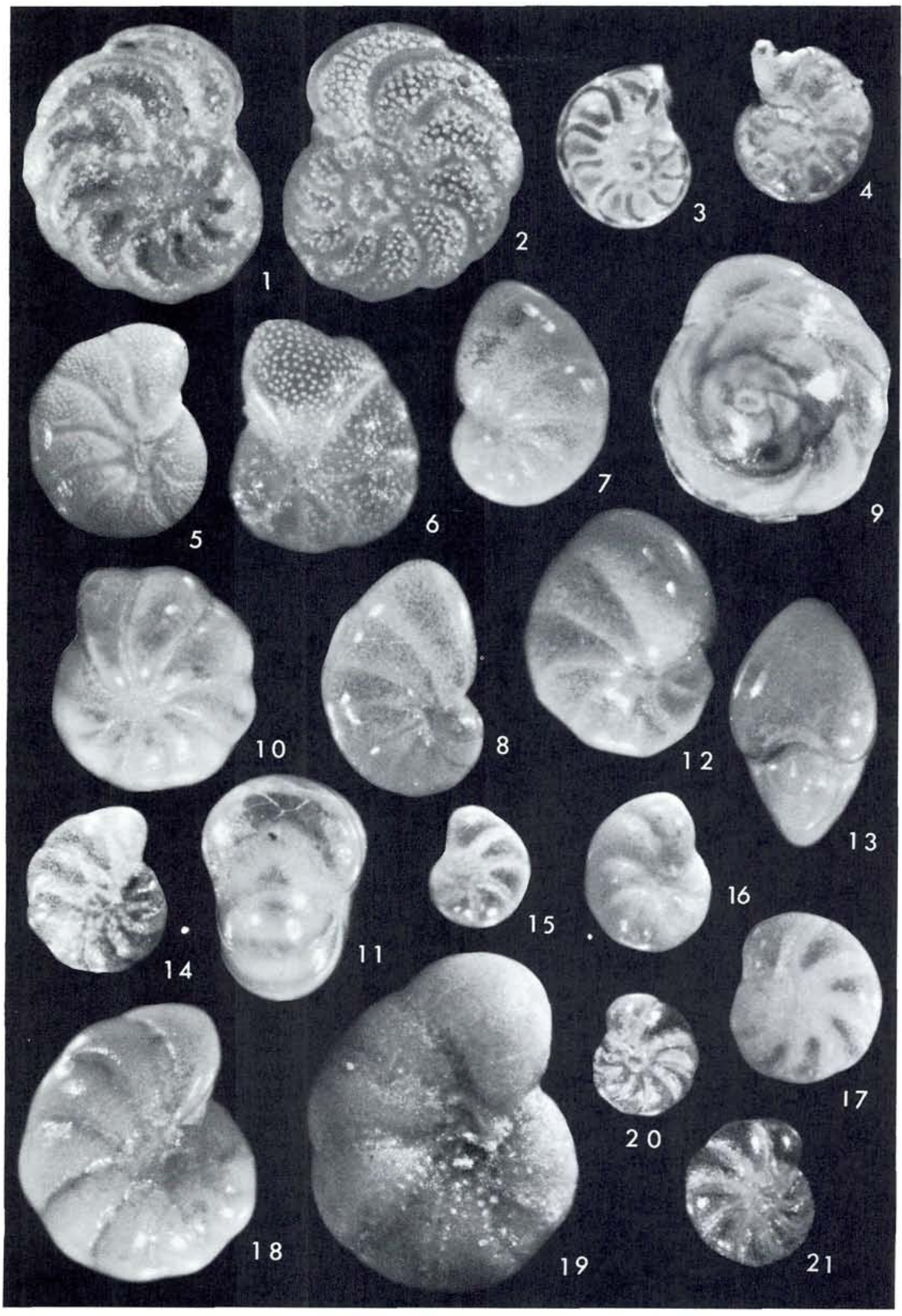


taining shallow-water foraminiferal assemblages which are not comparable with the North Sea assemblage from no. $23 b$.

An assemblage from Inner Silver Pit (Fisher et al., 1969) in the western part of the North Sea, analyzed by Knudsen (1973, p. 171) is dominated by Elphidium excavatum, $45 \%$, but has high frequency of Bulimina gibba (28\%), and Cassidulina laevigata, (17\%). However, Hyalinea baltica, Angulogerina angulosa and Planulina ariminensis do not occur in it. The occurrence was considered to be of Hoxnian age (Fisher et al., 1969).

If the Boreal foraminifera recorded by Jansen et al. (1979b) from a $1.32 \mathrm{~m}$ deep boring, 74-J $50 \mathrm{~B}-\mathrm{Z}$, in the northern North Sea, are Late Eemian of age, this is an other example of the discontinuous sedimentary record in the North Sea. Late Eemian deposits would then occur almost at the present sea floor at that bore site.

Zones $U, T$ and $S$ of the present boring are most probably Weichselian of age. Zone $U$ may represent an early cold part of that glacial age whereas zone $\mathrm{T}$ has much in common with Sandnes. Interstadial faunas, as known from borings and outcrops in the city of Sandnes, S. W. Norway; in the Jæren area south of Sandnes (Feyling-Hanssen, 1966, 1971, 1974); at Hirtshals in northern Jutland, Denmark (Andersen, 1971); and from Zone I of the Skærumhede II boring (Knudsen, 1976). Zone $\mathrm{T}$ is characterized by quite high frequency of Nonion labradoricum and Islandiella norcrossi, and zone 1 in Sandnes and zone $\mathrm{A}$ in Hirtshals are named the Nonion labradoricum-Islandiella norcrossi zone for the same reason. But the distances are considerable and local environmental peculiarities may have played a greater role than regional changes in age succession. If, however, this correlation is acceptable, the age of zone $\mathrm{T}$ should, on a general scale, stretch from $22,000 \mathrm{BP}$ to approximately 50,000 years BP.

If this is so, sediments from the time of the Weichselian maximum glaciation and onward to the Weichselian/Flandrian boundary are lacking or only represented by the $2 \mathrm{~m}$ thick zone $\mathrm{S}$ in the present boring.

Zone $\dot{Y}$ may represent one or more inter Saale interstadials, e.g., the Rügen Warmzeit of Wiegank (1972) or late or early Holstein interglacial deposits. The sampling interval is large, about $10 \mathrm{~m}$, in this part of the boring. Sediments of real interglacial character may occur between the sampled horizons. The presence of Cassidulina teretis which is known to be frequent in Early Quaternary and Late Tertiary deposits (Feyling-Hanssen, 1980), may even suggest that zone $\mathrm{Y}$ is older than the Holsteinian.

Correlation between the zones of the present boring and those of borings in the central North Sea (Holmes, 1977; Harland et al., 1978; Lord, 1980) and other recent borings in the northern North Sea has not been attempted in the present paper.

Acknowledgements. I am grateful to Tor Løken of the Norwegian Geotechnical Institute, Oslo, for placing the bore samples at my disposal and for advice and discussion concerning the material. I extend my thanks to Peter B. Konradi of the Geological Survey of Denmark, Copenhagen and to Karen Luise Knudsen, Department of Micropaleontology, Geological Institute of the University of Aarhus, who critically read the manuscript. I am grateful to J. R. Wilson, Geological Institute, Aarhus, who kindly improved the English of the text, to Svend Meldgaard, who processed the samples and provided the photographs for the plates, to Jette Gissel Nielsen, who drew location map and diagrams, and to Lissi Østerhaab Mogensen, who kindly prepared the manuscript. Permission to publish biostratigraphical information for the Statfjord Field from Mobil Exploration Norway Inc., Stavanger, on behalf of the Statfjord Group, is gratefully acknowledged.

\section{Dansk sammendrag}

Uforstyrrede prover fra en $120 \mathrm{~m}$ dyb boring i Kvartære aflejringer i Statfjord feltet i den nordlige Nordsø indeholdt velbevarede og rige foraminifer-selskaber. De allerfleste af disse var istidsfaunaer, nogle af stadial, nogle af interstadial karakter. Imidlertid fandtes $52 \mathrm{~m}$ under havbunden et utvivlsomt interglacialt selskab, varmekrævende foraminiferer udgjorde $71 \%$ af den bentoniske fauna. Den interglacial, som herved er repræsenteret, benævnes Statfjord Interglacialen og kan formodentlig korreleres med Eem Interglacialen i Nordvest Europa.

\section{References}

Andersen, A.-L. L. 1971: Foraminifera from the Older Yoldia Clay at Hirtshals, 159-184. In: Feyling-Hanssen, R. W., Jørgensen, J. A., Knudsen, K. L. and Andersen, A.-L. L. Bull. geol. Soc. Denmark 21 (2-3), 67-317.

Antevs, E. 1928: Shell beds on the Skagerack. Geol. Fören. Förh., 50 (4), 479-750.

Bahnson, H., Petersen, K. S., Konradi, P. B. and Knudsen, K. L. 1974: Stratigraphy of Quaternary deposits in the Skærumhede II boring: lithology, molluscs and foraminifera. Danm. geol. Unders., Arbog 1973, 27-62..

Feyling-Hanssen; R. W. 1955: Stratigraphy of the marine Late-Pleistocene of Billefjorden, Vestspitsbergen. Norsk Polarinst. Skr. 107, 1-186.

Feyling-Hanssen, R. W. 1958: Mikropaleontologiens teknikk. Norges Geol. Unders. 203, 35-48. 
Feyling-Hanssen, R. W. 1964: Foraminifera in Late Quaternary deposits from the Oslofjord area. Norges Geol. Unders. 225, 1-383.

Feyling-Hanssen, R. W. 1966: Geologiske observasjoner i Sandnes området (Geological observations in the Sandnes area, Southwest Norway). Norges Geol. Unders. 242, $26-43$.

Feyling-Hanssen, R. W. 1971: Weichselian interstadial Foraminifera from the Sandnes-Jaren area, 72-116. In: Feyling-Hanssen, R. W., Jorgensen, J. A., Knudsen, K. L. and Andersen, A.-L. L. Bull. geol. Soc. Denmark 21 (2-3), 67-317.

Feyling-Hanssen, R. W. 1972: The foraminifer Elphidium excavatum (Terquem) and its variant forms. Micropaleontology, 18, 337-354.

Feyling-Hanssen, R. W. 1974: The Weichselian section of Foss-Eigeland, Southwestern Norway. Geol. Fören. Stockholm Förh. 96, 341-353.

Feyling-Hanssen, R. W. 1980: Microbiostratigraphy of young Cenozoic marine deposits of the Qivituq Peninsula, Baffin Island. Marine Micropaleontology, 5, 153-184.

Feyling-Hanssen, R. W., Jørgensen, J. A., Knudsen, K. L. and Andersen, A.-L. L. 1971: Late Quaternary Foraminifera from Vendsyssel, Denmark and Sandnes, Norway. Bull. geol. Soc. Denmark 21 (2-3), 67-317.

Fisher, M. J., Funnell, B. M. and West, R. G. 1969: Foraminifera and pollen from a marine interglacial deposit in the western . North Sea. Yorkshire Geol. Soc., Proc. 37, 311-320.

Funnell, B. M. 1961: The Paleogene and Early Pleistocene of Norfolk. Transact. Norfolk and Norwish Natur. Soc. 19, 340-364.

Hansen, H. J. and Lykke-Andersen, A.-L. 1976: Wall structure and classification of fossil and recent elphidid and nonionid Foraminifera. Fossils and Strata, Nr. 10. Oslo. 1-37.

Harland, R., Gregory, D. M., Hughes, M. J. and Wilkinson, I. P. 1978: A late Quatemary bio- and climatostratigraphy for marine sediments in the north-central part of the North Sea: Boreas 7, 91-96.

Hessland, I. 1943: Marine Schalenablagerungen Nord-Bohusläns. Bull. Geol. Inst. of Upsala 31, 1-348.

Holmes, R. 1977: Quaternary deposits of the central North Sea between $56^{\circ}$ and $58^{\circ}$ N. Inst. Geol. Sci. Rep. 77/14, 1-50.

Jansen, J. H. F., Weering, T. C. E. van, Eisma, D. 1979a: Late Quaternary sedimentation in the North Sea. Symp. Univ. Ups. Ann. Quing. Cel. 2, 175-187.

Jansen, J. H. F., Doppert, J. W. C., Hoogendorn-Toering, K., De Jong, J., and Spaink, G. 1979b: Late Pleistocene and Holocene deposits in the Witch and Fladen Ground area, northern North Sea. Nederlands Jour. Sea Research 13 (1), 1-39.

Jessen, A., Milthers, V., Nordmann, V., Hartz, N. and Hesselbo, A. 1910: En Boring gennem de kvartare Lag ved Skærumhede. Danm. geol. Unders. II Rakke 25, 1-175.

Knudsen, K. L. 1973: The Lundergard Clay of Vendsyssel, Denmark, and its foraminifera. Bull. geol. Soc. Denmark 22 (3), 155-192.
Knudsen, K. L. 1976: Foraminifer faunas in Weichselian stadial and interstadial deposits of the Skærumhede boring, Jutland, Denmark. Maritime Sediments Spec. Publ. 1, B Paleoecology and Biostratigraphy, Halifax, 43-449.

Konradi, P. B. 1976: Foraminifera in Eemian deposits in Stensigmose, southern Jutland. Danm. geol. Unders. (II) 105, $1-57$.

Lafrenz, H. R. 1963: Foraminiferen aus dem marinen RissWürm-Interglazial (Eem) in Schleswig-Holstein. Meyniana 13, 10-46.

Lange, W. 1956: Grundproben aus Skagerrak und Kattegat, mikrofaunistisch und sedimentpetrographisch untersucht. Meyniana 5, 51-86.

Lord, A. R. 1980: Interpretation of the Lateglacial marine environment of NW Europe by means of Foraminiferida. In: Lowe, J. J., Gray, J. M., Robinson, R. E.: Studies in the Lateglacial of North-West Europe. Pergamon Press, Oxford, 103-114.

Lofaldli, M. 1973: Foraminiferal biostratigraphy of Late Quaternary deposits from the Frigg field and Booster Station. NTNF's Kontinentalsokkelkontor Publ., Oslo, No. 18, 1-82.

Moyes, J., Gayet, J., Pujol, C. and Pujos-Lamy, A. 1974: Etude stratigraphique et sédimentologique: CEPM-CNEXO, Orgon 1. Mer de Norwège, Aout 1974, 81-137.

Sejrup, H.-P. 1978: Foraminifer- og molluskanalyser av interglaciale marine sedimenter ved Fjøsanger, Bergen. Unpubl. thesis, Geological Institute B, University of Bergen, Norway. I, 1-89, II, 1-40, Appendix 1-40.

Sejrup, H.-P. and Guilbault, J.-P. 1980: Cassidulina reniforme and $C$. obtusa (foraminifera), taxonomy, distribution and ecology. Sarsia, 65, 79-85.

Sørensen, Aage Bach 1980: Kvartare aflejringers foraminiferer og stratigrafi $i$ vadehavet vest for Højer. Unpubl. thesis, Geological Institute, Aarhus University, Denmark, 1-146.

Voorthuysen, J. H. van 1949a: The Plio-Pleistocene boundary in the Netherlands based upon the ecology of Foraminifera. Me. Geol. Sticht., nieuwe Ser. 15, 63-69.

Voorthuysen, J. H. van 1949b: Foraminifera of the Icenian (Oldest marine Pleistocene) of the Netherlands. Nederlandsch Geol. Mijnbouw. Genootsch., Geol. Ser. 15, 63-69.

Voorthuysen, J. H. van 1957: Foraminiferen aus dem Eemien (Riss-Wûrm-Interglazial) in der Bohrung Amersfoort I (Locus typicus). Med. geol. Sticht. Nieuwe Ser. 11, 27-39.

Voorthuysen, J. H. van, Toering, K. and Zagwijn, W. H. 1972: The Plio-Pleistocene boundary in the North Sea basin, revision of its position in the marine beds. Geologie en Mijnbouw 51 (6), 627-639.

Walton, W. R. 1964: Recent foraminiferal ecology and paleo-ecology, 151-237. In: Imbrie, J. and Newell, N. D. (editors): Approaches to paleoecology. Wiley and Sons, New York.

Wiegank, F. 1972: Ökologische Analyse quartärer Foraminiferen Beitrag zur Quartärstratigraphie in der nördlichen Deutschen Demokratischen Republik. Geologie 21, Beiheft 77, 1-111. Berlin. 